\title{
Sekulariteter - förstahet genom religion och kön
}

Av Linda Berg, Mikela Lundahl och Lena Martinsson

\begin{abstract}
Secularities - firstness through religion and gender In this article we explore how positing religion as other simultaneously makes secularism a firstness. How is secularism embodied and reproduced as an objective and neutral space - a firstness. The secular subject is often represented as free and rational in contrast to an imagined religious, traditional, and often Muslim other. By studying Swedish contemporary debates about freedom of speech, veils, gender equality, and the in/tolerant society, we aim to unpack how secularism is done in a Swedish neoliberal contemporary context. Inspired by anthropologist of secularism, Talal Asad, we wish to contribute to the undermining of the tightly knit weave of secularism, reason and critique in Western discourse.
\end{abstract}

\section{KEYWORDS}

Secularism, firstness, intersection, veil, terrorist, Swedishness

Linda Berg är lektor i genusvetenskap vid Umeå universitet

Mikela Lundahl är lektor i idéhistoria vid Göteborgs universitet

Lena Martinsson är professor i genusvetenskap vid Göteborgs universitet

Författarna arbetar inom ett av det svenska Vetenskapsrådet finansierat forskningsprojekt om civilsamhället, där sekularitet/religiositet är en central intersektion. 


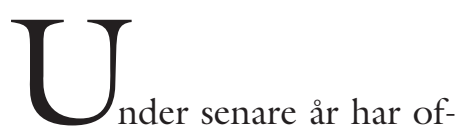
fentliga platser hamnat i centrum för en rad debatter som rör kön, sexualitet och islam. Ska badhus ha tider enbart för kvinnor? Ska kvinnor med slöja synas i reklam? Skrämmer bilder av muslimska kvinnor bort kunder? I dessa olika sammanhang refereras till en föreställd svensk jämställdhet och det ställs krav på begränsningar av vad som uppfattas som uttryck för islam och patriarkal kultur. I och genom dessa debatter skapas en förstahet som reproducerar sekulära ideal, och denna förstahet förstås som en neutral position från vilken religiösa uttryck antas kunna bedömas och kritiseras.

Att inte se hur den egna positionen präglar den egna kontexten, utan att uppfatta den som neutral är karaktäristiskt för förstahet. Det är samma rörelse som gör sekularitet till förstahet som gör religion och religiositet till annanhet (Asad 2009). Andras klädstilar, behov av avskildhet, eller andra kulturella uttryck som uppfattas som muslimska - och därmed religiösa - provocerar: liknande fenomen som uppfattas som kristna passerar som kultur eller tradition och ses därmed som sekulära och neutrala (Thurfjell 2015). Inom kategorin religion finns skillnader som dels har med grad att göra, och dels har med vilken religion det handlar om, där det kristna privilegieras framför det muslimska. Detta skapar konflikter på många nivåer och här kommer vi att utgå från några av dem som utspelats $\mathrm{i}$ svenska medier under de senaste åren.

Många sekularitetsforskare betonar hur sekularitet alltid förutsätter religion (Asad 2003, 2009; Mahmood 2012; Sigurdson 2015): Religion och sekularitet utgör varandras gränser. Dessa gränser är föränderliga och hur de förändras, läcker och omförhandlas, står i fokus för vårt intresse. Arbeten av Talal Asad $(2003,2009)$, Saba Mahmood (2012), Joan W Scott (2007) och Judith Butler (2009), samt diskussioner de fört sinsemellan, har inspirerat oss när vi har försökt att förstå den pågående normaliseringen av sekularitet och dess roll som förstahet i Sverige.

Liksom Asad och Mahmood är vi intresserade av det sekulära som en intersektion som bör analyseras tillsammans med modernitet, rationalitet, demokrati, aktivism, plats, nation och region (se även Raudvere 2015). Därigenom transformeras den till en politiskt performativ sekularism som inte bara skapar normer för hur det politiska livet ska ordnas utan också blir en dominant princip för hur samhälle och religion ska regleras. Religion trängs undan till de privata sfärerna och uppfattas som något som inte ska intervenera i politiska sammanhang eller i det offentliga livet. En återkommande föreställning i det material vi studerar handlar om att religion, åtminstone när det rör andra religioner än den protestantiska kristendomen, formar människors identitet, på en nivå som de inte antas ha tillgång till eller kontroll över, och därför måste de kontrolleras utifrån, medan de som identifiera sig som sekulära antas vara fria, rationella och i kontroll. Uppdelningen i "religiösa" och "sekulära" bidrar till att organisera vem som antas vara lämplig att agera och fă representeras i de politiska rummen. Den politiska sfären ska vara fri från religion och bestå av rationella individer som lämnat sin tro hemma och som internaliserat nationens normer och regelverk (se Das 2006). Det religiösa blir således särskilt, det ska inte prioriteras av staten eller ha en framträdande roll i det offentliga.

Denna performativa sekularism måste granskas, menar vi, eftersom den făr konsekvenser för de som andrafieras, och placeras utanför den kristna/sekulära föreställda gemenskapen. De andras livsutrymme, möjlighet att agera och påverka, kringskärs av det sekulära paradigmet. Samtidigt följer en universaliserande idé med sekularismen. Det sekulära samhället förmodas, på grund av sin uppfattade neutralitet kunna ge plats 
åt alla på ett jämlikt vis. Genom detta universella anspråk skyls sekularismens politiska och normativa aspekter (Asad 2009; Mahmood 2012; Thurfjell 2015).

\section{FÖRSTEHET OCH ANNANGÖRANDE I SVENSK PRESS}

Genom sin frekvens och sitt innehåll indikerar de debatter vi studerar en intensifiering av mediala och politiska diskussioner om sekularitet. Vi har valt två tydligt könade och sexualiserade debatter i en svensk kontext. En av dem har förekommit så ofta att den kommit att omtalas som slöjdebatten (Canoilas 2015). Slöjor får och har fătt betydelse för hur diskussioner om kön, sexualitet och kamp för kvinnors rättighet diskuteras och kopplas till religion (Farahani 2007; Karlsson Minganti 2007). "Slöjan" pekar ut en kvinnlig, religiös, märkt, rasifierad (Svensson 2015), muslimsk position, som blir en annanhet i förhållande till sekularismen, och figurationen "terroristen" utgör en manlig dito i den svenska debatten. I den här artikeln undersöker vi vad som upprepats, gjorts allmängiltigt och exkluderats i ett tjugotal artiklar och debattinlägg, för att fördjupa förståelsen av hur sekularitet konstrueras som förstahet i det samtida Sverige. De analyserade texterna är publicerade i etablerade medier som Dagens Nybeter (DN), Metro, Aftonbladet, Sveriges Television (SVT), Nyheter 24, Expressen, Sydsvenskan, Göteborgsposten. Det rör sig om några av de största dags- och kvällstidningarna, med stort genomslag i svensk offentlighet. Därutöver har vi tittat på några blogg- och hemsidesinlägg. De utvalda debatterna rör "bombdådet" 2010 i Stockholm, "hijabuppropet" år 2013, "slöjdebatten" 2015, samt ett fall med en terroristmisstänkt flykting 2015. Tidningsartiklarna består dels av nyhetsrapporteringar från olika händelser, dels av vittnesbörd om erfarenheter av våld, rasism och islamofobi, liksom av debatterande inlägg. Vår artikel syftar inte till att bidra till vetandet om des- sa händelser i sig utan om hur de förmedlas och medieras, och därmed bidrar till att skapa och reproducera narrativ om slöjor, terrorister, religion och makt, och i förlängningen om förstaheten sekularitet. Dessa narrativ kan sägas utgöra ett slags gränsgörande, där gränser utmanas, omförhandlas och återetableras. Gränser mellan vi och dom, och mellan det första och det andra. Det första utmanas av "nya" sätt att inta det offentliga rummet, och genom att definiera dessa som "andra" skapas nya narrativ om det första.

\section{MARKNADENS SEKULÄRA RUM?}

Marknadsplatsen är ett av de offentliga rum där gränser mellan religiositet och sekularism förhandlas. Ett exempel på detta är när en grupp som kallar sig "Kvinnors rätt", demonstrerade mot företagen HM och Åhléns för att de integrerat modeller iklädda slöjor i sina reklamkampanjer hösten 2015. Gruppen opponerade sig mot kampanjerna som enligt dem bidrog till att legitimera slöjan, vilken de ser som del av "könsapartheid" och därför inte bör förekomma i reklam eller på annat sätt bejakas i det offentliga rummet (Treijs 2015; Fagerlund Jerrstedt 2015; Madon 2015; Rashidi 2015):

Att göra en kampanj och reklam för slöjan tycker vi är kvinnoförtryck och könsapartheid, och det står vi upp mot, Maria Rashidi, ordförande i Kvinnors rätt och en av personerna bakom aktionen [...] Vi är emot att stora kapitalistiska företag tjänar pengar på vår bekostnad, vi kvinnor som flytt från diktator [sic] och förtryck (Carlén 2015).

Kvinnornas feministiska kritik mot kontroll av kvinnokroppar är direkt riktade till HM, och de uppfattar slöjor som olämpliga i offentliga reklamkampanjer. Genom att referera till egna erfarenheter, främst från Iran, av att som unga tvingats bära slöja, argumenterar de för Sverige som en modern 
plats, dit de flytt för att undkomma förtryck (Madani 2015). Nu upplever de att denna trygga plats hotas av marknadens inkluderingsstrategier. Kritiken riktar sig inte emot islam, utan mot vad de uppfattar som slöjans koppling till patriarkala strukturer, samt mot företagens kapitalistiska vinstintressen. Maria Rashidi understryker att de inte vänder sig emot kvinnor som bär slöja:

Jag har kompisar och vänner som är beslöjade, det är inte det vi är emot. Vi är emot att stora kapitalistiska företag tjänar pengar på vår bekostnad (Carlén 2015)

När klädföretagen kommenterar kritiken är inkludering ett bärande tema: “Åhléns är ett varuhus för alla och det vill vi visa $i$ vår kollektion". I HMs film, Close the loop, presenteras en mängd stilar, och huvudtesen är att alla stilar - i synnerhet stilbrott - är bra, men att återbruk är det bästa. I många av formuleringarna i filmen framhålls brott mot konventionella moderegler, som att blanda rosa och rött, eller att utmana normen att alltid ha svarta skor efter klockan 18. Modellen i slöja, som också associeras till normbrott, syns i knappt två sekunder av filmen som är 90 sekunder lång. Presskontakten på HM, säger i en intervju i Metro att Close the Loop visar upp en rad olika karaktärer: "Vi vill inte förmedla något specifikt ideal och vi tar ju varken politisk eller religiös ståndpunkt" (Carlén 2015).

Affärskedjornas svar uttrycker en sekulär hållning till slöjor, där förstahetens privilegium gör det möjligt att se religiositet som något som egentligen inte är särskilt betydelsefullt. Slöjbärare är kunder i första hand, och ges som sådana plats i offentligheten. Samtidigt töms slöjan på innehål, genom att den snarare blir en modeaccessoar, en vara bland andra. Detta sätt att närma sig slöjan är, som Asad (2003, 2009) belyser, ett exempel på hur marknaden styr och skapar mening i den förmodat neutrala sekulära offentligheten.

Flera av debattens aktörer använder pro- nomenet "alla" men med olika innehåll. För den protesterande gruppen upphörde varuhusen att vara till för dem i och med reklamkampanjen - de upplevde sig exkluderade ur Åhléns “alla”, som inte tar hänsyn till dem som flytt från förtryckande regimer, som tvingar kvinnor att bära slöjor. Reklamkampanjen uppfattades som en inskränkning av det svenska sekulära rummet. Åhléns "alla" ignorerar det faktum att slöjor gör olika saker, att de skapar olika former av inne- och uteslutningar och mobiliserar olika minnen och erfarenheter. Den kommersiella ambitionen att nå "alla" (kunder) är också i denna mening en universaliserande gest som inte erkänner skillnader. Genom att utgå från ett konsensusparadigm bäddar företaget för konflikt. Förstahetens diskurs, viljan att göra marknaden till ett ickereligiöst rum, upprepas både av marknadens kritiker och av dess representanter. Marknaden görs, av båda grupperna, till en viktig offentlig plats. Händelsen antyder alltså att sekularismen som normativt system inte bara styrs av marknaden utan också bidrar till att göra den central.

Kvinnogruppen var inte ensam om att vilja ha bort hijaben från reklamen. På webbsidan "Svenska hijabis" berättar Mariam som stylat modellerna i annonsen att protesterna kom från fler håll: hon menar att även forskare ville ha bort hijabreklamen.

Islamofober var emot Åhlénsreklamen, de menade att man inte ska blanda in religion $\mathrm{i}$ mode. En manlig forskare som inte ens är muslim skrev en debattartikel mot och fick uttala sig väldigt mycket. Men våra röster får knappt höras (Svenska Hijabis 2015).

Den manliga forskaren som det refereras till är sannolikt Devin Rexvid, doktorand i socialt arbete vid Umeå universitet. Rexvid deltog aktivt i förberedelserna av demonstrationen mot HM och Åhléns genom att starta facebookgruppen "Nej till normalisering av slöjan" som syftade till att genom- 
föra en protestaktion. ${ }^{1}$ Precis som de protesterande kvinnorna refererar han till sin egen erfarenhet i Iran, men han kopplar sin kritik tydligare till religion och "islamisk indoktrinering". Han kritiserar islam för att vara våldsbejakande och kvinnoföraktande (Rexvid 2015).

Gemensamt för Rexvids uttalanden, och kvinnorna som demonstrerade utanför HM och Åhléns, är att de, genom att identifiera sig som offer för en patriarkal struktur utanför Sverige, gör anspråk på ett inifrånperspektiv. De skapar en plattform som framstår som mer legitim och trovärdig än till exempel vår - som vita privilegierade feminister uppväxta i huvudsak i sekulära miljöer. Genom att hänvisa till egna erfarenheter laddar de sina röster med autenticitet och får tillgång till en roll som legitima islamkritiker. De upprepar en bild av sig själva som rationella och sekulära medborgare som värnar om den svenska jämställdheten. Samtidigt positionerar de sig i konflikt med muslimska feminister som uttalat stödjer kampanjen, som får dem att känna sig sedda och inkluderade (Treijs 2015). Den senare gruppen uppfattar sig inte som offer för vare sig en kapitalistisk eller patriarkal struktur. Den protesterande kvinnogruppen framställer de slöjbärande som partikulära röster, utan universell giltighet. De slöjbärande kritiseras inte som individer, men deras närvaro i de offentliga rummen ska inte legitimeras av stora aktörer. Den protesterande kvinnogruppen själva däremot gör anspråk på rollen som representanter för den sekulära förstaheten.

Reaktionerna på HMs film visar hur laddad slöjan är. I filmen presenterades okonventionella klädstilar men dessa väckte inte debatt: män i kjol tycks samtiden redo för. ${ }^{2}$ Slöjor, och den därmed associerade tanken på kvinnans förmodat utsatta position, provocerar däremot och idén att bruna kvinnor måste räddas från bruna män (formulerad av Spivak, 1988, för att beskriva brittisk kolonialism under första halvan av 1800-talet) dominerar ännu det offentliga samtalet om kön och sexualitet. Alla unga, vackra och starka, och till synes klasslösa, modeller utgör potentiellt material till diskussioner om hur HM med sitt starka varumärke förvaltar sin direktkanal till världens unga.

I anslutning till debatten om HM intervjuas skribenten och aktivisten Bilan Osman. Hon var en av dem som startade det hijabuppror som vi strax återkommer till. I intervjun poängterade Osman "att det är dags att ta tillbaka makten över slöjan och istället ta itu med problematiken som slöjan bara är en symbol för” (Fagerlund Jerrstedt 2015). Osman öppnar för en kritik både mot en förenklad förståelse av marknadens "öppenhet" och mot att förstå slöjan som enbart ett uttryck för det patriarkala. Både marknaden och det patriarkala samhället är problematiska, men också föreställningen om sekularitet som en överordnad position.

Inför julhandeln 2015 fick en grupp ungdomar knutna till barn- och ungdomsverksamheten i Burlövs kommun, strax utanför Malmö, i uppdrag att måla en vägg i ett köpcentrum. Målningen godkändes av köpcentrumets ledning och skulle spegla mångfalden i samhället och i ungas vardag. Bilden föreställde en äldre man, en kvinna i slöja, en annan kvinna i studentmössa och ett litet barn. Media rapporterar att kvinnan i slöja väckte oönskade känslor. Ledningen som redan godkänt bilden ändrade sig och fick deltagarna i ungdomsgruppen att måla om bilden, och förvandla den till en kvinna med långt hår. Bilden av kvinnan av-slöjades, vilket antogs neutralisera bilden:

Vi insåg att det förekom en religiös symbol på målningen och det kan inte vi stå för, säger Pernilla Olsson, som är centrumchef för köpcentret, men som poängterar att detta inte är hennes personliga åsikt utan att hon talar för ägaren Grosvenor (Lindström 2015).

Olsson understryker i Sydsvenskan att religion och köpcentrum inte hör ihop. och att julen är en "rent kommersiell högtid":

Vi ska vara politiskt och religiöst neutrala. 
Vi ska aldrig ta ställning i några debatter som gäller kön, politik eller religion. Vi ska välkomna alla. [...] Julen är en kommersiell högtid och vi är ett köpcentrum. Det är under julen som en stor del av handeln sker, och vi måste sälja produkter, varor och tjänster för att kunna överleva.

Journalisten frågar om religiösa symboler får förekomma om de kan kopplas till försäljningen:

Tycker du att pepparkakor och jultomtar är religiösa symboler? Vi anser inte det. Det här är en rent kommersiell högtid, och det är sådana produkter som folk vill köpa nu (Karlsson 2015).

Så görs den sekulära förstaheten i en marknadskontext. Marknaden vänder sig bara till dem som kan köpa: inte till “alla”. Ekonomisk ojämlikhet osynliggörs och hänvisningen till "alla" blir ytterligare exempel på hur förstahet skapas. I Burlöv uppfattades en målad slöja som något som kunde avskräcka köpcentrumets "alla", medan HM och Åhléns uttryckte en annan uppfattning om hur “alla” borde avgränsas. Några inkluderar en slöja i sin katalog över kläder och accessoarer, andra retuscherar bort en slöja. Slöjor fungerar som gränsobjekt (se Ask 2014). Deras betydelse är instabil och offentliga aktörer vet inte hur de ska använda dem, eller vilka reaktioner de kan generera.

Hur Burlövs köpcentrum väljer att hantera och kommentera uppståndelsen synliggör sekularismens ambivalenta förhållande till religion. Julen antas inte vara religiös utan en höjdpunkt för detaljhandeln. Det är sant att julen i sin helhet inte kan reduceras till en kristen högtid: i sin nuvarande form kan den närmast beskrivas som Bengt Kristensson Ugglas beskriver det svenska Luciafirandet: “en ganska så avancerad synkretistisk blandning av moment från katolsk helgontro och en serie fornnordiska motiv" (2015: 44), därtill kommersialiserad. Men inte i så hög grad att dess kristna inramning helt raderats ut. Ave Maria spelades i köpcentrumets musikanläggning, vilket visar hur integrerad kristenheten är i hegemoniska traditioner och ofta inte ens uppfattas som religion (Kristensson Uggla 2015; Thurfjell 2015). Det är också ett exempel på hur sekularism blir en del av en marknadsideologi och tömmer en religiös högtid på dess religiösa innehåll.

Slöjan på väggen provocerar däremot och kopplas till religion - vilket uppfattas som inkompatibelt med det offentliga kommersiella rummet. Ambitionen var att visa mångfald, men den ambitionen kolliderade med sekularitetsnormen. Samtidigt finns en toleransnorm som inte låter oss peka ut en enskild religion - och därmed riskera att uppfattas som islamofoba eller rasistiska. Förstaheten innehåller olösta konflikter som samtiden samt förstaheten undviker eftersom den gör anspråk på att vara rationell i motsats till politisk och därmed erkänns inte dessa konflikter (Mouffe 2005).

Inget tyder i sig på att ledningen för Burlövs centrum har starka åsikter för eller emot slöjan. De har synpunkter på vad som är bra eller dåligt för affärerna och de verkar inte riktigt veta hur det är med slöjor: Är slöjbärande kvinnor en viktig kundgrupp? Eller är de som stöts bort av slöjan på väggen viktigare? En bild på en beslöjad kvinna målas om till en kvinna med utslaget hår i förvissning att den då blir neutral. Här uppfattas slöjan som religiös, medan julhelgens inramningar med bakgrund i kristen religion inte ses som motsägande den sekulära normen.

Debatten kring den av-slöjade kvinnan i Burlövs centrum fortsatte även efter ommålningen, när det antirasistiska nätverket Tillsammans ifrågasatte händelseutvecklingen. Också ledare för ungdomsgruppen som genomfört målningen, samt en bibliotekarie som varit indragen i projektet, kritiserade köpcentrumets agerande på sociala medier. Kritiken följdes upp i traditionella medier (Aftonbladet och Sydsvenskan). Köpcentrumet ändrade sig igen och gick ut 
med en pressrelease på hemsidan där man bland annat skrev:

Vi beklagar att en väggmålning på en kvinna med slöja, en Hijab, i Burlöv Centrum uppfattats som en religiös symbol och därför ändrats. Att bilden ändrades var olyckligt.

Intressant nog har denna formulering försvunnit från webbsidan och nu finns ett mer tillrättalagt pressmeddelande:

Efter dialog med ungdomarna har vi fått djupare information gällande deras grundtankar med konstverket - att alla är välkomna, mångfald och allas lika värde. Mötet ledde till det gemensamma beslutet att återställa målningen såsom det ursprungligen var tänkt. Det innebär att slöjan som tidigare målades över, kommer att målas tillbaka. Vi vill be om ursäkt till ungdomarna vars konstprojekt vi förändrade och är ledsna över de reaktioner som ungdomarna har fått ta emot. Vi ser fram emot att konstverket färdigställs och att vi gör det tillsammans (Grosvenor 2015).

Köpcentrumet uppfattade slöjan som religiös, och "muslimsk", vilket uppfattades som ett religiöst inslag som inte kan härbärgeras (Thurfjell 2015; Gunnarsson 2016). I nästa meddelande har köpcentrumet ändrat sig. Nu blir religiösa inslag en del av mångfalden och köpcentrumet ansluter sig därmed till den mångfaldsdiskurs, och dess problem, som upprepades av HM och Åhléns. Frågan blir om slöjan också, precis som julen, nu måste tömmas på religiösa innebörder och bli en kommersiell tradition? I sin bok Katedralens hemlighet. Sekularisering och religiös övertygelse (2015) diskuterar Kristensson Uggla debatterna kring skolavslutningar och huruvida de skall ske i kyrkorum eller ej, och finner där en parallell process, där skolledningar för att kunna "behålla vissa populära psalmer löste [det] genom att helt enkelt omdefiniera dem från uttryck för religion och andlighet till kultur och tradition" (a.a.: 37).
Saba Mahmood poängterar att tron inte kan skiljas från subjektsskapande och att tro inte kan betraktas som något som kan tas av och på eller lämnas hemma (2004). Det är knappast möjligt att inte "ta med" sig sin tro när en går in i politiska eller andra offentliga rum. Händelserna på köpcentrumet indikerar att det inte går att ställa det religiösa bortom det uppfattat sekulära samhället (jfr Moodod 2013; Gunnarsson 2016). Drömmen om den neutrala sekulära platsen är en dröm om den ständigt flexibla individen, som kan lämna tron där hemma, som om den bara var en accessoar.

\section{MEDBORGARSKAPETS RUM.}

\section{SEKULÄRT JAG, RELIGIÖS ANNAN}

Om slöjor har kommit att bli en självskriven del i hur muslimska kvinnor framställs, har även föreställningar om muslimska män sin tydliga katalog. Mia Eriksson skriver i Berättelser om Breivik (2016) om hur figuren "terrorist" kopplas samman med den muslimska bruna mannen, och hur majoritetssvenskars (i detta fall) rädsla därigenom klibbar fast vid honom (Hübinette 2012; Eriksson 2016; Ahmed 2004). Genom att uttrycken för diskursen om den farliga bruna mannen är så frekventa har de bildat ett slags raster som varje man som kan ha en koppling till Mellanöstern tolkas igenom. De tvingas förhålla sig till detta raster som, med Sara Ahmeds terminologi, klibbar fast vid dem. Detta klibbiga raster delar upp svenska män, i de första som vitifieras, sekulariseras - eller möjligen görs kristna och uppfattas som goda, och i de andra som görs religiösa, potentiellt fundamentalistiska och farliga (Bredström 2002). I linje med västerländska orientalistiska idéer tenderar stereotyper om muslimska män grundade i essentialistiska uppfattningar om "religion" och "kultur" att reproduceras närmast av sig själva (Gottzén \& Jonsson 2012 ). Föreställningar om religion och kultur associeras med våld och tvång, och upprättar muslimska män som potentiella kvin- 
noförtryckare och våldsverkare utifrån en förståelse av dessa som religiöst och kulturellt styrda. I december 2010 detonerade två explosioner i centrala Stockholm, och mannen bakom avled. Händelsen klassificerades som ett terrordåd, bland annat med hänvisning till hot som skickades $\mathrm{i}$ anslutning till dådet, och bland annat innehöll kritik mot konstnären Lars Vilks samt mot eventuell svensk militär intervention i Afghanistan. Svenska Muslimer för Fred och Rättvisa organiserade redan samma kväll en fredsmanifestation samt uttalande avstånd från våld och argumenterade för att händelsen riskerade att elda på hat och hot mot muslimer (Sveriges Radio 2010). Man hänvisade bland annat till islamofoba föreställningar om rasifierade muslimska män i Sverige.

Efter attentaten i Paris i november 2015 aktualiserades liknande föreställningar i medierna. En ung man som just anlänt till Sverige från Iran pekades ut som potentiell terrorist, och eftersöktes över hela Sverige. Suddiga bilder på en man som passade in på stereotypen av den muslimska terroristen spreds i många tidningar. Säkerhetspolisen höjde terror-risknivån från 3 till 4 på en 5 -gradig skala. När han själv gav sig till känna i Boliden visade det sig att han var oskyldig (så oskyldig en muslimsk man nu kan vara givet detta raster). Hans muslimska identitet och muslimska namn hamnade i fokus (Nolervik 2015). Sverige framställdes som en plats där religion inte har en framträdande roll. När han själv kom till tals märktes hans vilja att närma sig den förstahet han redan hunnit uppfatta:

Mannen: Ingen här är ond. Jag kom till Sverige, världens fredligaste land, för att få lugn och ro, för jag sökte fred.

Journalisten: Du var på alla löpsedlar, ditt namn och din bild fanns överallt och du var dömd som terrorist på förhand, vad tänker du om det nu?
Mannen: Jag bryr mig bara om att människor vet sanningen nu. Jag var misstänkt på felaktiga grunder, och jag vill att det svenska folket ska förstå att jag inte är någon terrorist. Jag är bara en vanlig kille, som knappt är religiös. Jag ber bara ibland.

Den oskyldigt anklagade tvingas positionera sig i förhållande till stereotypen av den muslimska mannen - den potentiella terroristen - som han inte vill förknippas med och som inte passar med hans bild av Sverige. Han försäkrar läsaren om att han är en "vanlig kille". Han "ber bara ibland". Han understryker att religionen bara är en relation mellan honom och Gud och inte spelar någon roll för hans offentliga liv. Det sekulära kravet fungerar som en styrande och ordnande kraft, trots att detta krav inte är uttalat, men förstaheten syns heller inte nödvändigtvis (Brade 2010).

\section{MODERNA SUBJEKT}

Ibland blir det anti-religiösa våldet som framställs i reportagen mycket konkret, som när en gravid kvinna som bar hijab, misshandlades på en parkering i stockholmsförorten Farsta i augusti 2013. En främmande man rapporterades ha slitit $\mathrm{i}$ hennes slöja och kläder, samtidigt som han skrikit att "såna som du ska inte vara här" (Delling 2013).

Händelsen utgjorde startskottet för det så kallade hijabuppropet då antirastister och människorättsorganisationer uppmanade kvinnor att gemensamt visa stöd för muslimska kvinnor, och deras rätt att bära slöja. Under rubriken "Imorgon beslöjar vi oss i solidaritet" skrev debattörerna Bilan Osman, Fatima Doubakil, Foujan Rouzbeh, Nabila Abdul Fattah och Nachla Libre i Aftonbladet:

Med anledning av det inträffade kommer vi härmed att utlysa ett hijabupprop. Vi upp- 
manar alla medsystrar i Sverige - religiösa som icke-religiösa - att under i morgon den 19 augusti beslöja sig i syfte att visa solidaritet med alla muslimska kvinnor som alltför ofta får utstå trakasserier och våld (Osman 2013).

Debattörerna uppmanade till att hatbrott mot muslimer ska utredas bättre, och i synnerhet att brott riktade mot kvinnor som bär slöja ska granskas noggrannare. Uppropet besvarades främst på sociala medier där många lade ut bilder på sig själva i slöja, och somliga manifesterade på gator och offentliga platser. ${ }^{3}$ Hijabuppropet fick stor uppmärksamhet, och såväl nationella som internationella medier rapporterade om det. Acceptans och tolerans av hijab blev ett av journalistiken sanktionerat sätt att inkorporera det avvikande, en berättelse om det toleranta samhället där uppropet dessutom blev ett försvar för det sekulära demokratiska samhället. I Expressen valde journalister att skriva om hur hijabuppropet uppmärksammats över hela världen, som al-Jazeera och BBC News.

Uppropet kom emellertid snart att kritiseras på sociala medier och i debattartiklar. Sara Mohammed och Virpi Hellmark menade att "hijabupprop tar fokus från förtryckaren och förtrycket" (Mohammad \& Hellmark 2013). De poängterade att uppropets uppmärksammande av rasism, samtidigt negligerade att slöjan kan vara ett uttryck för kvinnoförtryck. Jenny från organisationen Femen hävdar i en artikel på SVT Debatt att hon "klär av [s]ig i solidaritet" med hijabuppropets budskap, och ovanför texten finns en bild på henne där hon drar upp tröjan, blottar brösten och hon har skrivit slagord på sin kropp som My Body My Rules Not God's Not Allah's. Slöjbärande får representera tvång och religion, i kontrast till det fria barbröstade eller bärande av förmodat självvalda kläder. I kritiken av slöjbärande, framstår slöja som en symbol för religiositet och förtryck och frånvaron av slöja signalerar frihet, indivi- duella val och autonomi - och förstahet (Röstlund 2013a).

Qaisar Mahmood, chef för Riksantikvarieämbetets kulturmiljöavdelning, och författare till boken Jakten på svenskheten, lyfte i en artikel fram hur debatten om uppropet visade på svårigheten att se att hijab kan representera såväl förtryck som rättighet. Mahmood framhöll att hijab inte kan betraktas som en universell symbol som betyder samma sak oberoende av tid och rum (2013).

En annan kritik handlade om ett synande av den förmodat solidariska handlingen. Intervjuer görs med vita kvinnor som testat att bära slöja, ett föreställt “oss” får berätta om upplevelsen av att tillfälligt uppträda som “dem". I Aftonbladet berättar Kristin om hur hon utsatts efter att ha burit slöja på en tågresa tillsammans med sin son:

- Det var obehagligt. Jag blev ledsen, min son blev ledsen. Om det är så här för mig i två timmar... Jag hoppas innerligt att det inte är så här för kvinnor som normalt bär slöja. Det här visar att det är en fråga som verkligen behöver tas upp (Röstlund 2013b).

Om en vit, blond, sekulär eller kristen kvinna väljer att bära hijab för en dag förväntas läsaren stanna upp och lyssna. Läsaren förväntas, likt Kristin, inte vara någon som “normalt bär slöja”. Det blir ett sätt att låta läsaren få del av detta andra perspektiv, men av någon som inte ständigt lever med slöja som berättar. Istället för en "autentisk" röst som delger sin erfarenhet, bjuds läsaren på en förmodat "neutral" sekulär röst som efter att ha tagit av sig slöjan kan erbjuda ett objektivt vittnesmål med distans till frågan. En röst som representerar förstahet och därmed andas trovärdighet. Sara Yazdanfar, aktiv i SSU, betvivlar möjligheten att påverka, om inte förstaheten făr syn på sig själv. En tillfällig förändring av en facebookprofil uppfattas som att "slöjan blev kosmetik. Ett sätt att göra sig själv till ett subjekt snarare än att fokusera på just hatbrott, rasismen 
och sexismens samverkan". Yazdanfar menar vidare att uppropet kom att förskjutas och tas över av en vit medelklass som genom sitt agerande exotiserar muslimska troende kvinnor, samtidigt som de är omedvetna om sina egna privilegier (Yazdanfar 2013). Yasdanfar uppmärksammar svårigheten i att försätta sig i de andras position: Konfrontationen med det vita sekulära/icke-muslimska väcker behov av att försvara de egna handlingarna och argumentera för att de leder till ökad förståelse av den andre.

I Qaisar Mahmoods och Sara Yazdanfars kritik och problematisering är det således inte definitionen av hijab som förtyck eller frigörelse som sätts i fokus, utan vit sekulär förstahet, och hur den sätter sig själv i första rummet även när den avser att vara solidarisk, som synas. De riktar blicken mot det toleranta Sverige, där muslimska kvinnor făr sitt värde via förstahetens artikulerade välvillighet, då även de icke-välvilliga kan tolkas som avvikande utifrån det toleranta samhällets ambition att vara inkluderande. Utan att reducera politik till levd erfarenhet uppmanar dessa kritiker sekulära medsystrar att stanna upp och rikta blicken mot egna normativa positioner.

\section{KAMP OM SEKULÄRA RUM}

Genom att följa några stråk ur en sedan länge pågående debatt i Sverige om "slöjan" och "terroristen" har vi försökt visa hur sekulära argument och handlingar utgör en förstahet. Denna förstahet blir till både genom att exkludera religion: främst islam, och genom att sekularitet sammanflätas med andra förstaheter, eller intersektioner, som modernitet, vithet, svenskhet, objektivitet och marknaden. Sannolikt upprättas sekulära rum i Sverige oavbrutet utan att nämnvärd friktion uppstår. Exemplen i den här artikeln är emellertid uttryck för en intensifierad andrafiering där konflikter uppstått och där förstaheten, som inte behöver benämnas eller beskrivas, åberopas som kontrast till de som görs avvikande.
Vi har uppmärksammat hur det muslimska andra förskjuts från gemensamma rum. Sekularitet framstår som det neutrala, som samhällets kärna, och troende, framförallt muslimer, förväntas anpassa och förminska sin tro, privatisera den. Tro omtalas och uppfattas som något som kan lämnas hemma, som sekundärt i förhållande till jaget. Att de som identifierar sig med sekulära positioner kan ställa krav som dessa, visar i sig på sekularismens privilegierade position och innehåll.

Sekularismens karaktär av förstahet innebär också att den framstår som omärkt, som ett objektivt och naturligt centrum för de som privilegieras av den. Sekularismen fungerar som en värderande performativ plats och identitet där ras, kön, sexualitet, samhälle, nationalitet görs inom det binära fältet religiös-sekulär. När den första framställs som normal, begriplig och rationell och därmed överordnad produceras samtidigt en bild av den andra som irrationell, traditionell, och potentiellt farlig. Likt tomma signifikanter pekas "slöjan" och "terroristen" ut och används i kampen om det offentliga rummet. De har blivit motsägelsefulla könade och rasifierade symboler för religiositet, irrationalitet och hot om våld. Diskursen om "terroristen" har bidragit till att religion uppfattas som farlig, och därmed blir sekularismen än mer naturaliserad och privilegierad.

Förstaheten står inte fri från yttre och inre utmaningar och den är lika lite entydig som de processer genom vilka andrafiering sker. Att lyfta fram mångtydigheten hos den sekulära förstaheten är en väg att erbjuda motstånd mot att religioner reproduceras som multipla, heterogena, utmanande och motsägelsefulla, medan sekularitet uppfattas som entydig, rationell och stabil (Butler, Mendieta \& VanAntwerpen 2011: 70f). Vi har lyft fram motsägelsefullheten hos några av de krafter som underbygger sekularitet. I debatten som uppstod efter publiceringen av HMs och Åhléns reklam innehållande slöja, försvarades det sekulära 
idealet både av marknadskritiska och marknadsförespråkande röster. Vi har också visat hur nära förbundna sekularism och marknadskrafter är, och hur sekularitetens förmodade neutralitet och rationalitet därigenom begränsas. Sekularitet och marknad ger varandra mening, liksom sekularism och kapitalism går hand $\mathrm{i}$ hand.

Samtidigt som "slöjan" exkluderas och görs till objekt kan den synliggöra sekularismens gränser. Kvinnor i slöja har länge lästs som offer för patriarkala strukturer och som offer kan de inte erkännas som jämbördiga medborgare i ett liberalt, tolerant och modernt samhälle (Braidotti 2008). En medborgare förmodas vara en med andra jämlik kraft. Feministiska inflytelserika muslimska röster riskerar därmed att förminskas (Badran 2009; Hassan 1999). Den feministisk-muslimska kritiken mot sekularismens effekter har i viss mån avbrutit en pågående materialisering av sekulär hegemoni och synliggjort de naturaliseringsprocesser som gör muslimska kvinnor till offer istället för medborgare (se Butler 1993; Trinh 2011). Slöjor som artefakter och i kraft av sin performativa styrka har fått betydelse för hur kön och sexualitet diskuteras i offentliga såväl som privata rum under senare år. De är komplexa och mångsidiga och de utmanar såväl den hegemoniska sekularismen som den liberala förståelsen av den fria individen. Sekularismens roll kritiseras och religionen sätts $\mathrm{i}$ fokus och försvaras av aktivister, ett försvar som exempelvis kan ske genom upprop för det andrafierade, eller genom att sätta fokus på sekularismen och dess våldsamma effekter.

För att kunna leva tillsammans i skillnad behöver fantasin om en given neutral plats, oavsett om den framställs som sådan av marknaden eller i radikal aktivism, utmanas. Sekularism är också diskurser, positioner och identiteter, som producerar annanhet samtidigt som den producerar sig själv som förstahet. Att förstå sekularism som förstahet, som ett pågående görande av hegemoniska normer innebär att se religion och se- kularism som intrasslade i varandra också inom enskilda trossystem. Genom att se denna intrassladhet som tillblivelse av normativ hegemoni ser vi hur sekularism uttrycker makt och ojämlika relationer i dagens svenska samhälle.

\section{Noter}

1. "Nej till normalisering av slöjan", 2015.

2. Tidstypiskt nog går det bra att utmana könsnormer inom det som uppfattas som västligt och sekulärt. De senaste decenniernas kamp mot homofobi har utvidgat utrymmet för hur både män och kvinnor får se ut. Så länge de är sekulära och västliga. 3. Se Berg \& Carbin, 2015, för en fördjupad analys av hijabuppropet.

\section{LITTERATUR}

\section{- Ahmed, Sara (2004): The Cultural Politics of} Emotions. Edinburgh University Press and Routledge, Edinburgh.

- Asad, Talal (2009): Free Speech, Blasphemy, and Secular Criticism, in: T. Asad et al. (eds.): Is Critique secular? Blasphemy, Injury, and Free Speech. Townsend Papers in Humanities, Berkeley. - Asad, Talal \& Brown, Wendy (2013): Introduction Free Speech, Blasphemy, and Secular Criticism, in: T. Asad et al. (eds.): Is Critique secular? Blasphemy, Injury, and Free Speech. Townsend Papers in Humanities, Berkeley.

- Asad, Talal, Brown, Wendy, Butler, Judith \& Mahmood, Saba (2013): Is critique secular? Blasphemy, injury, and free speech. Fordham University Press, New York.

- Ask, Jenny (2014): Muslimska moderskap och modrandets villkor i Sverige. Stockholms universitet, Stockholm.

- Badran, Margot (2009): Feminism in Islam. Secular and Religious Convergences. Oneworld, Richmond.

- Berg, Linda \& Carbin, Maria (2015): Solidariska selfies: Anti-rasistiskt engagemang i en digitaliserad samtid, i: Eric Carlsson, Simon Lindgren, Bo Nilsson (red.), Digital Politik. Sociala medier, deltagande och engagemang. Daidalos, Göteborg. - Brade, Lovise Haj Z. (2010): De(t) u/morkede. En undersogelse af tilskreven og subjektiv forstehed 
blandt mandlige danske ingeniører, Kandidatspeciale, Sociologisk institut, Københavns universitet. - Braidotti, Rosi (2008): In Spite of the Times. The Postsecular Turn in Feminism. Theory, Culture \& Society, 25(6): 1-24.

- Bredström, Anna (2002): Maskulinitet och kamp om nationella arenor - reflektioner kring bilden av 'invandrarkillar' i svensk media, i: Paulina De los Reyes, Irene Molina \& Diana Mulinari (red.): Maktens (o) lika förklädnader. Kön, klass \& etnicitet $i$ det postkoloniala Sverige. Stockholm.

- Butler, Judith (1993): Bodies that matter. On the Discursive limits of "Sex". Routledge, New York. - Butler, Judith (2009): Frames of War: When Is Life Grievable? Verso, New York.

- Butler, Judith; Mendieta, Eduardo \& VanAntwerpen, Jonathan (2011): The power of religion in the public sphere. Columbia University Press, New York.

- Canoilas, Viviana (2015): Gina Dirawis kritik mot SVT: Diskriminerande, Expressen, 3 okt. - Carlén, Linnea (2015): De protesterar mot H\&M och Åhléns kampanjer med kvinnor i slöja, Metro, 12 okt.

- Darvishpour, Mehrdad (2014): Jämställdhet, etnicitet och "andra män" - ett intersektionellt perspektiv på förändringar av maskulinitet efter migration. Fritzes, Stockholm.

- Das, Vena (2006): Secularism and the Argument from Nature, i: David Scott \& Charles Hirschkind: Power of the Secular Modern. Talal Asad and his Interlocutors. Stanford University, California.

- Delling, Hannes (2013): Slöjuppror efter misshandel, Svenska Dagbladet, 19 aug.

- Eriksson, Mia (2016): Berättelser om Breivik. Affektiva läsningar av våld och terrorism. Makadam förlag, Göteborg \& Stockholm.

- Fagerlund Jerrstedt, Karin (2015): Nu använder modeföretagen slöja i sin reklam, SVT Nyheter, 19 sept.

- Farahani, Fataneh (2007): Diasporic narratives of sexuality: identity formation among IranianSwedish women. Diss. Stockholms universitet, Stockholm.

- Gottzén, Lucas \& Jonsson, Rickard (2012): Goda män och Andra män, i: Lucas Gottzén \& Richard Jonsson (red.): Andra män. Maskulinitet, normskapande och jämställdhet. Gleerups, Malmö. - Grosvenor, Pressrelase, Burlövs center (2015). Finns i författarnas arkiv. - Gunnarsson, David (2016): Güst i Sverige. Sanningsregimer, villkorade själv(re)presentationer och nationell tillhörighet vid moskévisningar i Stockholm. Stockholms universitet. Stockholm.
- Hassan, Riffat (1999): Feminism in Islam, in: Arvind Sharma \& Katherine K. Young (eds.): Feminism and world religions. State of Uni of NY Press, Albany.

· Hübinette, Tobias (2012): 'Ord som sårar': Om bristen på en interkulturell etik i ett samtida Sverige, i: Katrin Goldstein-Kyaga, María Borgström \& Tobias Hübinette (red.): Den interkulturella blicken i pedagogik. Inte bara goda föresatser. Södertörn University, Huddinge.

- Karlsson Minganti, Pia (2007): Muslima. Islamisk väckelse och unga kvinnors förhandlingar om genus $i$ det samtida Sverige. Carlsson, Stockholm.

- Karlsson, M Johanna (2015): Slöja målades över i Burlöv center, Sydsvenskan, 28 nov.

- Kristensson Uggla, Bengt (2015): Katedralens hemlighet. Sekularisering och religiös övertygelse. Artos \& Norma bokförlag, Skellefteå.

- Lindström, Emma (2015): Slöja målades över i Burlöv - budskapet var för religiöst, Nyheter 24, 29 nov.

- Madani, Nasrin (2015): Åhléns tjänar pengar genom att förtrycka kvinnor med slöja, Nybeter 24, 24 sept.

- Madon, Sakine (2015): Försvara rätten att vägra slöja, feminister, Expressen, 2 okt.

- Mahmood, Qaisar (2013), Viktigt upprop, men fel symbol, Svenska Dagbladet, 23 aug.

- Mahmood, Saba (2004): Politics of Piety. The

Islamic Revival and the Feminist Subject. Princeton University Press.

- Mahmood, Saba (2009): Religious Reason and Secular Affect: An incommensurable Divide?, in: T. Asad, et al. (eds.): Is Critique secular? Blasphemy, Injury, and Free Speech. Townsend Papers in Humanities, Berkeley.

- Modood, Tariq (2013): Muslims, Religious Equality and Secualrism, i: Anders Berg Sorensen (ed.): Contesting Secularism. Comparative Perspectives. Ashgate, Farnham.

- Mohammad, Sara \& Hellmark, Virpi (2013): Hijabupptropet är ett hån mot kvinnoaktivister, Göteborgs-Posten, 21 aug.

- Mouffe, Chantal (2005): On the political. Routledge, London.

- Nej till normalisering av slöjan (2015): https://www.facebook.com/groups/104499425219 $7452 /$ ?fref $=$ ts

- Nolervik, Stefan (2015): För en vecka sedan uthängd som Sveriges farligaste man - i kväll bjuder Moder alla på fest", Östersunds-Posten, 28 nov.

- Osman, Bilan et al. (2013): I morgon beslöjar vi oss av solidaritet, Aftonbladet, 8 aug.

- Rashidi, Maria (2015): Varför gör ni reklam för könsapartheid, Expressen, 7 okt. 
- Raudvere, Catharina (2015); Islam: An Introduction. I. B. Tauris, London.

- Rexvid, Devin (2015): Att hata islam är inte en fobi, Svenska Dagbladet, 24 jan.

· Röstlund, Lisa (2013a): Bär slöja till stöd för muslimska kvinnor. Kritiker: Vad håller de på med? Aftonbladet, 19 aug.

- -- (2013b): Kristin orkade bara bära slöja två timmar, Aftonbladet, 19 aug.

- Scott, Joan (2007): Slöjans politik. Tankekraft förlag, Stockholm.

- Sigurdson, Ola (2015): Det postsekulära tillståndet-religion, modernitet, politik. Glänta produktion, Göteborg.

- Spivak, Gayatri Chakravorty (1988): Can the Subaltern Speak?, i: Cary Nelson \& Lawrence Grossberg (eds.): Marxism and the Interpretation of Culture: Communications and Culture. Macmillan Education, Houndmills.

- Svenska Hijabis, http://svenskahijabis.se/intervjuer/mariam, nedladdat den 19 januari 2016.
- Svensson, Therese (2015): Alla rasifieras, Mana, 18 Juni.

- Sveriges Radio (2010): Oro och ilska bland muslimska organisationer, $13 \mathrm{dec}$.

. SVT Debatt (senare Opinion) (2013): Jag klär av mig naken i solidaritet med hijabuppropet (Jenny, Femenaktivist).

- Thurfjell, David (2015): Det gudlösa folket: de postkristna svenskarna och religionen. Molin Sorgenfrei förlag, Stockholm.

- Treijs, Erica (2015): Orimligt att ett tygstycke ska ha sådan påverkan, Svenska Dagbladet, 27 sept. . Trinh T. Minh-ha (2011): Elsewhere, within here. Routledge, New York.

- Yazdanfar, Sara (2013): Fokusera på antirasism, inte på selfies, Dagens Arena, 22 aug. - Åbonde, Jenny (2015): Försvara rätten att vägra slöja, feminister, Omni (Sveriges största nyhetsapp), 3 okt, http://omni.se/topic/3b5e3f420f85-49b8-9461-bf6cld4900e4/d9652d38277b-474e-a2b0-05a436986202 